\title{
CORPORATE SOCIAL RESPONSIBILITY TERHADAP MANAJEMEN LABA DAN KINERJA PERUSAHAAN
}

\author{
Devi Dwi Rahmawardani \\ devidwirahmawardani@gmail.com \\ Muslichah \\ STIE Malangkucecwara \\ Jl. Terusan Candi Kalasan, Blimbing, Mojolangu, Malang, Jawa Timur 65142
}

received: 25/2/2020; revised: 30/7/2020; approved: 28/10/2020

\begin{abstract}
This study aims to analyze the direct and indirect effects of Corporate Social Responsibility (CSR) on company performance through earnings management. The objects in this study are companies incorporated in LQ45 in the 2016-2018 period. Samples were taken using a purposive sampling method. The data of this study were analyzed using path analysis. The results showed four important findings: (1) the influence of CSR on company performance is positive and significant, (2) CSR has a negative and significant effect on earnings management, (3) the effect of earnings management on company performance is not significant (4) earnings management cannot mediate the effect of CSR on company performance.
\end{abstract}

Keywords: csr; corporate performance; LQ45; earnings management; path analysis

\begin{abstract}
Abstrak
Penelitian ini bertujuan untuk menganalisis pengaruh langsung dan tidak langsung Corporate Social Responsibility (CSR) terhadap kinerja perusahaan melalui manajemen laba. Objek dalam penelitian ini adalah perusahaan yang tergabung dalam LQ 45 pada periode 2016-2018. Sampel diambil dengan menggunakan metode purposive sampling. Data penelitian ini dianalisis menggunakan analisis jalur. Hasil penelitian menunjukkan empat temuan penting: (1) pengaruh CSR terhadap kinerja perusahaan adalah positif dan signifikan, (2) CSR berpengaruh negatif dan signifikan terhadap manajemen laba, (3) manajemen laba tidak berpengaruh terhadap kinerja perusahaan (4) manajemen laba tidak dapat memediasi pengaruh CSR terhadap kinerja perusahaan.
\end{abstract}

Kata Kunci: csr; kinerja perusahaan; LQ45; manajemen laba; analisis jalur 


\section{PENDAHULUAN}

Pada umumnya tujuan didirikannya perusahaan adalah untuk menghasilkan laba. Tetapi akhir - akhir ini para pemangku kepentingan menuntut perusahaan tidak hanya mengejar laba semata tetapi juga melakukan tanggung jawab sosial (Fernández-Guadaño \& SarriaPedroza, 2018; Cho et. al, 2019; Akben-Selcuk, 2019). Perusahaan yang baik harus melakukan kepedulian terhadap kelestarian di lingkungan sekitar, kesejahteraan masyarakat sekitar dikarenakan perusahaan tidak hanya mendapatkan laba yang besar tetapi dalam melaksanakan kegiatan operasionalnya, perusahaan akan terlibat dalam kegiatan tersebut. Menurut Hadi (2011) bahwasannya Corporate Social Responsibility pada dasarnya memulai dari filosofi bagaimana cara mengelola perusahaan memiliki dampak positif bagi dirinya dan lingkungannya. Oleh karena itu, perusahaan harus bisa mengelola bisnis operasinya dengan menghasilkan produk dalam orientasi yang bersifat positif terhadap masyarakat dan lingkungan.

Perusahaan yang melakukan CSR mendapat lebih banyak manfaat seperti menarik lebih banyak investor, biaya modal yang lebih rendah, reputasi yang baik dan kinerja keuangan yang lebih baik (Esteban-Sanchez et. al, 2017). Keterlibatan perusahaan dalam program CSR diharapkan dapat membangun citra positif bagi pemangku kepentingan, yang pada akhirnya diharapkan dapat berdampak dengan meningkatnya kinerja perusahaan.

Beberapa penelitian terdahulu telah mencoba untuk mengkaji pengaruh pengungkapan $C S R$ terhadap kinerja perusahaan, tetapi hasilnya penelitian masih tidak konsisten. Penelitian tersebut diantaranya sudah dilakukan oleh Saleh et. al. (2011); Kamatra \& Kartikaningdyah (2015); Mahrani \& Soewarno (2018); Simaremare \& Gaol (2019); Akben-Selcuk (2019); Cho et. al. (2019) dimana temuannya menunjukkan bahwa CSR berpengaruh positif herhadap kinerja perusahaan. Sedangkan penelitian yang dilakukan oleh Mwangi and Jerotich (2013), Parengkuan (2017), Santoso (2017) menemukan bahwa CSR tidak berpengaruh terhadap kinerja perusahaan. Ketidak konsistenan hasil penelitian terdahulu tersebut mengisyaratkan adanya variabel lain yang mempengaruhi hubungan antara CSR dan kinerja perusahaan, diantaranya adalah manajemen laba (Mahrani \& Soewarno, 2018).

Manajemen laba diartikan sebagai upaya manajemen perusahaan untuk mempengaruhi informasi dalam laporan keuangan perusahaan guna untuk menarik calon investor. Informasi laba merupakan informasi yang penting bagi investor sebagai dasar pengambilan keputusan dalam berinvestasi. Manajemen laba terjadi ketika manajemen tidak mencapai target dalam pencapaian labanya, maka manajemen melakukan modifikasi laporannya dengan menerapkan metode akuntansi yang dapat menunjukkan informasi pencapaian laba dan kinerja yang lebih baik. Scholtens \& Kang (2012) menyatakan bahwa perusahaan dapat menghindari manajemen laba dengan melakukan pengungkapan yang lebih banyak. Peningkatan informasi dalam pengungkapan laporan keuangan akan menurunkan asimetri informasi. Dengan demikian, peningkatan pengungkapan menyebabkan fleksibilitas manajer untuk melakukan manajemen laba akan berkurang karena menurunnya asimetri informasi antara manajemen dengan stakeholders. Penelitian terdahulu yang dilakukan oleh Kim, et. al. (2012); Nastiti (2010); dan Ricardo \& Faisal (2015) menjelaskan bahwa CSR berpengaruh negatif dan signifikan terhadap manajemen laba. Perusahaan yang memiliki tanggung jawab sosial dan berkomitmen dalam kebijakan CSR akan mendorong manajer mengurangi tindakan yang tidak etis dalam praktik manajemen laba.

Manajemen sebagai pengelola perusahaan diharapkan untuk dapat lebih transparan dalam mengungkapkan informasi keuangan perusahaannya sehingga dapat membantu dalam pengambilan keputusan oleh pihak-pihak yang berkepentingan (stakeholders) termasuk pemilik perusahaan. Sehingga pengambilan keputusan dapat dilakukan berdasarkan laporan keuangan yang disajikan manajemen, maka informasi yang disampaikan harus relevan dan dapat dipercaya. Dalam hal ini informasi yang disampaikan oleh manajemen kepada stakeholders adalah informasi yang sebenarnya mengenai kondisi perusahaan. Beberapa penelitian terdahulu yang menjelaskan mengenai pengaruh manajemen laba terhadap kinerja perusahaan diantaranya adalah Prasetyo, et. al. (2017); Ekawiguna \& Darmansyah (2017); Fitriyani, et. al. (2014).

Penelitian ini mengembangkan penelitian sebelumnya dengan memasukkan manajemen laba sebagai variabel yang memediasi pengaruh $C S R$ terhadap kinerja perusahaan menjadi satu model penelitian. Berdasarkan penjelasan diatas, maka yang menjadi tujuan penelitian ini adalah untuk menganalisis pengaruh $C S R$ terhadap kinerja perusahaan melalui manajemen laba.

Peneliti melakukan penelitian pada Perusahaan Indeks LQ45 yang terdaftar di BEI pada periode 20162018. Perusahaan Indeks LQ45 dipilih dikarenakan memiliki nilai kapitalisasi pasar yang besar, saham saham yang banyak diminati oleh investor di pasar modal Indonesia serta mempunyai tingkat likuiditas tinggi.

Stakeholder adalah pihak-pihak yang dapat mempengaruhi maupun dipengaruhi perusahaan. Perusahaan bukan entitas yang beroperasi untuk kepentingannya sendiri namun harus juga memberikan manfaat bagi stakeholder-nya Ghozali dan Chariri (2007). Stakeholder memiliki kemampuan untuk mempengaruhi pemakaian sumber-sumber daya yang berada di masyarakat. Ketika stakeholder mengendalikan 
sumber daya yang penting bagi perusahaan, maka perusahaan akan bereaksi dengan cara memuaskan keinginan stakeholder (Ullman 1985, dalam Ghozali dan Chariri, 2007).

Freeman (1983) memperkenalkan konsep stakeholder dalam dua model: (1) model kebijakan dan perencanaan bisnis; dan (2) model tanggung jawab sosial perusahaan dari manajemen stakeholder. Pada model pertama, fokusnya adalah mengembangkan dan mengevaluasi persetujuan keputusan strategis perusahaan dengan kelompok-kelompok yang dukungannya diperlukan untuk kelangsungan usaha perusahaan. Sementara dalam model kedua, perencanaan perusahaan dan analisis diperluas dengan memasukkan pengaruh eksternal yang mungkin berlawanan bagi perusahaan.

Keterbatasan kepentingan yang ada dalam suatu perusahaan harus diminimalisasi agar tidak menimbulkan permasalahan, untuk mencegah masalah terjadi maka diperluakan jasa pihak lain (agen) untuk membantu pelaksanaan sehhingga tujuan yang diinginkan dapat tercapai. Brigham dan Houston (2006) mengutip dari Jensen and Meckling 1976 menjelaskan bahwa teori keagenan yang terdapat pada perusahan terjadi karena terdapat perbedaan kepentingan antara pemilik perusahaan dengan manajer yang telah diberikan delegasi tugas dan wewenang.

Menurut Fatoni, et. al. (2016) legitimacy theory merupakan hubungan kontrak antara perusahaan dan masyarakat. Dalam teori tersebut dijelaskan bahwa suatu perusahaan akan berupaya untuk menyesuaikan keadaan yang berlaku di masyarakat berupa peraturanperaturan sehingga dapat diterima dilingkungan eksternal. Dowling dan Pleffer (1975) dalam Ghozali dan Chariri (2007) menjelaskan bahwa teori legitimasi sangat bermanfaat dalam menganalisis perilaku dalam organisasi dengan batasan batasan yang ditekankan oleh nilai nilai dan norma sosial serta reaksi terhadap batasan tersebut mendorong pentingnya analisis perilaku organisasi dalam meperhatikan lingkungan.

Gray, et. al. (1995) mengatakan bahwa praktek CSR yang dilakukan oleh perusahaan digunakan untuk memanipulasi kebutuhan informasi para stakeholder yang ada di masyarakat seperti karyawan, pemegang saham, agen non-pemerintah dan masyarakat untuk memperoleh dukungan mereka. Dukungan dari para stakeholder merupakan hal yang penting bagi perusahaan agar tetap dapat bertahan hidup ataupun untuk meningkatkan nilai dan laba perusahaan. Praktek CSR merupakan suatu kegiatan yang penting bagi perusahaan agar tetap dapat bertahan hidup.

Menurut Scott (2009), mendefinisikan manajemen laba sebagai suatu tindakan manajemen di suatu perusahaan dalam memilih kebijakan akuntansi untuk standar tertentu agar mencapai target laba tertentu, yang bertujuan memaksimalkan kesejahteraan pihak manajemen atau nilai perusahaan. Ada 2 cara pemahaman yang dapat dipergunakan untuk memahami manajemen laba Scott (2006). Pertama, manajemen laba adalah sebagai peluang untuk manajer guna meningkatkan kepentingan pribadinya, dan bisa dikenal dengan oportunistic earnings management. Kedua, manajemen laba dapat juga dipandang dari perspektif efficient contracting management adalah manajemen laba digunakan oleh manajer sebagai jalan keluar guna melindungi kepentingan perusahaan untuk mengantisipasi kejadian-kejadian tak terduga guna meningkatkan keuntungan pihak yang terlibat

The World Business Council for Sustainable Development (WBCSD) mendefinisikan CSR atau tanggung jawab sosial perusahaan, sebagai: Continuing commitment by business to behave athically and contribute to economic development while improving the quality of life of the workforce and their families as well as of the local community and society at large. Pembahasan ini mengenai CSR adalah, Komitmen dalam dunia bisnis yang berkelanjutan untuk memberikan kontribusi terhadap pembangunan ekonomi yang berkelanjutan serta meningkatkan kualitas hidup masyarakat sekitar yng berdampak mendapatkan lingkungan yang lebih baik. CSR merupakan strategi perusahaan yang mengakomodasi kebutuhan dan kepentingan stakeholder-nya untuk tujuan pertumbuhan berkelanjutan, selain itu perusahaan mempunyai fokus tidak hanya pada manfaat bagi diri sendiri, namun ikut ambil berperan dalam proses pertumbuhan masyarakat dan lingkungan.

Kinerja merupakan hal penting untuk menilai kemampuan perusahaan dalam mengelola serta mengalokasikan sumber dayanya. Menurut Mulyadi (2001). Pengertian penilaian kinerja adalah penentuan secara periodik efektivitas operasional dalam suatu organisasi, bagian dalam organisasi serta karyawannya berdasarkan sasaran, standar dan kriteria yang sudah ditetapkan. Indikator yang digunakan untuk mengukur profitabilitas dalam penelitian ini yaitu, Return on Equity (ROE), Return on Asset (ROA) dan Profit Margin (PM). Tiga ukuran dalam rasio ini merupakan ukuran yang sering dikenal dan paling luas penggunaanya di antara semua rasio keuangan lainnyan (Ross, et. al, 2009).

Hasil dari penelitian Mahrani dan Soewarno (2018) menyebutkan bahwasannya peningkatan CSR dapat dilakukan oleh perusahaan melalui peningkatan penilaian kinerja lingkungan yang selanjutnya dapat meningkatkan kinerja perusahaan. Upaya perbaikan lingkungan akan mendapatkan hasil yang positif dari investor serta dampak meningkatkan citra perusahaan. Meningkatnya citra perusahaan tersebut ini memberikan sinyal positif bagi stakeholders. Stakeholder disini berupa kepercayaan terhadap produk produk yang dihasilkan oleh perusahaan sehingga meningkatkan keuntungan perusahaan. Keuntungan perusahaan ini nantinya akan berdampak terhadap kinerja perusahaan itu. 
Penelitian terdahulu menunjukkan bahwa $C S R$ berpengaruh positif terhadap kinerja perusahaan (Pramana dan Yadnyana, 2016; Bhernadha, et. al 2017; Mahrani dan Soewarno, 2018, Akben-Selcuk, 2019; Cho, et. al, 2019). Hal ini dapat diintrepretasikan bahwa semakin tinggi perusahaan mengungkapan CSR, semakin tinggi pula kinerja perusahaan. Dengan kata lain semakin banyak pengungkapan CSR maka kinerja perusahaan akan semakin baik.

Menurut Kim, et. al. (2012), adanya kegiatan tanggung jawab sosial (CSR) pada laporan tahunan akan membuat informasi keuangan lebih terpercaya bagi pihak-pihak yang menggunakan laporan keuangan. Scholtens \& Kang (2012) dalam penelitiannya menyatakan bahwa perusahaan dapat menghindari manajemen laba dengan melakukan pengungkapan CSR yang lebih. Perusahaan yang lebih banyak mengungkapkan informasi mengenai aktivitas pertanggungjawaban sosial perusahaannya akan lebih membatasi untuk melakukan praktik manajemen laba. Penelitian terdahulu yang dilakukan oleh Kim, et. al (2012); Nastiti (2010); Putri (2012); Putra \& Palguna (2013) menemukan bahwa CSR berpengaruh negatif terhadap manajemen laba. Hal ini dapat dijelaskan bahwa perusahaan yang memiliki tanggung jawab sosial dan berkomitmen dalam kebijakan CSR akan mendorong manajer mengurangi tindakan yang tidak etis dalam ptaktik manajemen laba. Dengan adanya pengungkapan tanggung jawab sosial akan membuat pelaporan keuangan menjadi transparan sehingga mendorong manajer untuk mengurangi praktik manajemen laba.

Laba adalah komponen penting bagi berbagai pihak yang berkepentingan dengan perusahaan. Manajemen perusahaan akan berusaha menyajikan laba yang sesuai dengan harapan para calon investor, sehingga mereka tertarik untuk menginvestasikan uangnya ke perusahaan. yaitu dengan cara melakukan manajemen laba. Menurut Scott (2009) manajemen laba merupakan tindakan manajemen untuk memaksimalkan kualitas manajemen melalui memilih kebijakan prosedur akuntansi agar mencapai target laba yang diinginkan, yang tujuan memaksimalkan kesejahteraan berbagai pihak yang berkepentingan serta meningkatkan kinerja perusahaan.

Dalam penelitian Lestari dan Anjelina (2014), dan Challen dan Siregar (2017) menemukan bahwa manajemen laba berpengaruh positif terhadap kinerja perusahaan. Dengan adanya pengaruh yang positif antara manajemen laba terhadap kinerja perusahaan, dapat diartikan bahwa perusahaan melakukan manajemen laba dalam rangka meningkatkan kinerja perusahaan.

Laporan CSR merupakan bagian dari pengungkapan informasi yang dilakukan pihak perusahaan kepada pihak ketiga melalui laporan tahunan. Aktivitas CSR dilakukan oleh perusahaan sangat membutuhkan dukungan atau legitimasi dari masyarakat sekitar perusahaan, agar perusahaan dapat beroperasi dengan aman. Adanya kegiatan tanggung jawab sosial pada laporan tahunan akan membuat informasi keuangan lebih terpercaya bagi pihak-pihak yang menggunakan laporan keuangan (Kim, et. al, 2012).

Pengungkapan tanggung jawab sosial akan membuat pelaporan keuangan menjadi transparan sehingga dapat mengurangi praktik manajemen laba dan manajer dapat memaksimalkan kualitas manajemennya dengan memilih kebijakan prosedur akuntansi agar mencapai target laba yang diinginkan, yang tujuan memaksimalkan kinerja perusahaan dan kesejahteraan bagi pemegang saham maupun pihak-pihak yang berkepentingan (Scott , 2009). Kim, et. al, (2012) dan Scott, (2009) menjelaskan bahwa manajemen laba dapat memediasi efek CSR terhadap kinerja perusahaan. Manajemen melakukan kebijakan prosedur akuntansi dalam upaya membentuk maksimalisasi pendapatan serta minimalisasi pendapatan. Berdasarkan pengembangan hipotesis maka model penelitian ini dapat digambarkan pada Gambar 1.

\section{METODE}

Populasi dalam penelitian ini adalah perusahaan yang terdaftar di Bursa Efek Indonesia dan termasuk di dalam kelompok LQ45, yaitu berjumlah 45 perusahaan. Sampel dalam penelitian ini adalah perusahaan yang berturut-turut terdaftar sejak tahun 2016-2018 serta menyediakan informasi yang diperlukan dalam penelitian ini. Jumlah perusahaan yang memenuhi kriteria tersebut berjumlah 31 Perusahaan. Proses Pemilihan Sampel Berdasarkan Purposive Sampling. Prosedur penentuan sample dapat dilihat pada Tabel 1.

\section{HASIL}

Tabel 2 menunjukkan bahwa rata-rata nilai CSR berada pada kisaran 0,7316 menunjukkan bahwa CSR perusahaan sebesar $0,7316 \%$ dari total pengungkapan yang dimiliki. Untuk deviasi standar 0,42687 sedangkan minimum sebesar 0,36 yang ditunjukan oleh Bumi Serpong Damai Tbk yang bergerak dibidang property and real estate, sedangkan nilai maksimum sebesar 1,95 yang ditunjukan oleh perusahaan H.M. Sampoerna Tbk, yang bergerak dibidang tobacco manufacturers. Tabel 2 juga menunjukkan bawa nilai rata-rata untuk kinerja perusahaan adalah 0,2742 dengan deviasi standar 0,30233 sedangkan nilai minimum sebesar 0,02 yang ditunjukkan oleh Bumi Serpong Damai Tbk yang bergerak dibidang property and real estate dan nilai maksimum sebesar 1,22 yang ditunjukkan oleh Unilever Indonesia Tbk yang bergerak dalam bidang cosmetics and household. Selanjutnya, manajemen laba berada pada nilai rata-rata sebesar 0,6507 . Deviasi standar sebesar 0,92270 dengan kisaran nilai minumun 0,03 dan maksimum 4,88. Nilai minimum ditunjukan pada perusahaan Bank Mandiri (Persero) Tbk yang bergerak 
di bidang perbankan, sedangkan nilai maksimum ditunjukkan Bumi Serpong Damai Tbk yang bergerak dibidang property and real estate.

Tabel 3 menunjukkan bahwa pengaruh CSR terhadap kinerja perusahaan menunjukkan nilai koefisien jalur sebesar 0,680 , dengan nilai $\mathrm{p}=0,000(<0,05)$. Hasil tersebut mengindikasikan bawa CSR berpengaruh positif signifikan terhadap kinerja perusahaan, dengan demikian hipotesis 1 diterima.

Dari Tabel 3 diketahui bahwa pengaruh CSR terhadap manajemen laba menunjukkan hasil koefisien jalur sebesar -0,131 dan signifikan pada tingkat 0,05 (nilai $\mathrm{p}=0,000<0,05$ ). Sehingga dapat disimpulkan bahwa pengaruh CSR berpengaruh negatif signifikan terhadap manajemen laba signifikan, yang berati hipotesis 2 diterima.

Tabel 3 menunjukkan hasil pengaruh manajemen laba terhadap kinerja perusahaan, dimana hasil koefisien jalur sebesar $-0,207$ dan nilai $p=0,114>0,05$. Nilai tersebut mengindikasikan bahwa pengaruh manajemen laba terhadap kinerja perusahaan tidak signifikan. Sehingga dapat disimpulkan bahwa hipotesis 3 ditolak.

Untuk dapat mengetahui peran manajemen laba sebagai variabel mediasi antara CSR dengan kinerja perusahaan, maka kedua jalur harus signifikan. Pada Tabel 3 diketahui bahwa jalur pertama yaitu pengaruh CSR terhadap manajemen laba signifikan. Sedangkan jalur kedua yaitu pengaruh manajemen laba terhadap kinerja perusahaan tidak signifikan. Karena salah satu jalur tidak signifikan, maka dapat disimpulkan bahwa manajemen laba tidak memediasi pengaruh CSR terhadap kinerja perusahaan. Dengan demikian H4 ditolak.

Selanjutnya, Tabel 4 memperlihatkan hasil pengaruh CSR terhadap kinerja perusahaan melalui manajemen laba. Tabel tersebut menunjukkan penjumlahan pengaruh langsung dan tidak langsung. Pengaruh langsung variabel $C S R$ terhadap kinerja perusahaan sebesar 0.680, sedangkan pengaruh total CSR terhadap kinerja perusahaan melalui varibel manajemen laba diperoleh nilai sebesar 0.473 yang berarti nilai pengaruh total lebih kecil dibandingkan nilai pengaruh langsung dan dapat disimpulkan bahwa variabel manajemen laba tidak memberikan pengaruh antara variabel $C S R$ terhadap kinerja perusahaan.

\section{PEMBAHASAN}

Penelitian ini menunjukkan 4 temuan penting. Pertama, CSR berpengaruh positif signifikan terhadap kinerja perusahaan. Peningkatan CSR dapat dilakukan oleh perusahaan melalui peningkatan kinerja lingkungan, sosial dan ekonomi, yang pada akhirnya dapat meningkatkan kinerja perusahaan. CSR ditujukan kepada pemangku kepentingan, oleh karenya harus mampu memenuhi harapan dan kebutuhan para pemangku kepentingan. Aktivitas CSR dapat meningkatkan citra perusahaan, karena pemangku kepentingan eksternal memberikan penilaian yang baik terhadap perusahaan, akibatnya semakin banyak konsumen yang akan membeli produk atau layanan perusahaan sehingga kinerja keuangan perusahaan akan meningkat (Lenssen, et. al, 2011). Hasil penelitian ini mendukung penelitian terdahulu yang dilakukan oleh Gantino, (2016); Pramana dan Yadnyana (2016); Bhernadha, et. al (2017); Mahrani dan Soewarno (2018); Simaremare \& Gaol (2019); Akben-Selcuk (2019); Cho, et. al (2019) yang menemukan adanya pengaruh positif $C S R$ terhadap kinerja perusahaan. Hal ini dapat diinterpretasikan bahwa dengan adanya kegiatan CSR yang dilakukan terus menerus oleh perusahaan akan membuat masyarakat percaya atas kinerja sosial perusahaan, selain itu perusahaan juga dapat memperoleh informasi sebanyaknya mengenai perusahaan dari masyarakat. Investor akan lebih mempercayakan modal yang mereka tanamkan kepada perusahaan, sehingga perusahaan akan lebih mudah untuk menggunakan modal tersebut untuk aktivitas perusahaan dalam rangka meningkatkan kinerja perusahaan.

Kedua, Temuan penelitian ini menunjukkan bahwa CSR berpengaruh negatif signifikan terhadap manajemen laba. Pengungkapan kegiatan CSR merupakan salah satu bagian pengungkapan informasi yang dilakukan pihak perusahaan kepada pihak ketiga melalui laporan tahunan. Aktivitas CSR dilakukan perusahaan karena membutuhkan dukungan dari lingkungan masyarakat agar perusahaan dapat beroperasi dengan aman. Dengan kata lain, perusahaan memerlukan pengakuan dari masyarakat sekitarnya. CSR mencerminkan transparansi yang dapat mengurangi perilaku oportunistik manajer untuk tindakan manajemen laba. Hasil penelitian ini mendukung hasil temuan dari Kim, et. al (2012) dan Nastiti (2010). Kim, et. al (2012) menjelaskan bahwa pelaporan CSR merupakan pelaporan dari aktivitas tanggung jawab sosial bagi investor, pelanggan, dan pihak stakeholder lainnya yang menuntut transparansi yang lebih besar mengenai semua aspek bisnis. Dengan adanya pelaporan $C S R$, laporan tahunan menjadi lebih terpercaya bagi investor maupun pihak yang menggunakan laporan tersebut dalam pengambilan keputusan.

Ketiga, hasil penelitian menunjukkan bahwa manajemen laba tidak berpengaruh terhadap kinerja perusahaan. Hal ini mengindikasikan bahwa besar kecilnya manajemen laba yang dilakukan pihak manajemen perusahaan tidak berpengaruh signifikaan pada kinerja perusahaan. Terdapat dua alasan terkait hasil yang tidak konsisten tersebut. Pertama, kondisi pasar modal Indonesia masih tidak efisien dimana dalam pengambilan keputusan berinvestasi di pasar modal para investor juga melihat dan mempertimbangkan kondisi di luar perusahaan dan isu yang beredar. Kedua, tujuan manajer untuk melakukan manajemen laba seperti tujuan bonus dan penghematan pajak. Hal tersebut yang menjadi tujuan utama manager dalam melakukan manajemen laba jika dibandingkan dengan tujuan meningkatkan kinerja keuangan. Hasil 
penelitian ini mendukung penelitian terdahulu yang dilakukan oleh Dyah (2013) dan Yip \& Nguyen (2012) yang mengemukakan bahwa manajemen laba tidak berpengaruh terhadap kinerja perusahaan.

Keempat, Berdasarkan hasil yang diperoleh pada penelitian ini menemukan bahwa manajemen laba tidak memediasi pengaruh CSR terhadap kinerja perusahaan. Dapat dijelaskan bahwa dikarenakan pemangku kepentingan belum mampu menganalisis informasi yang diterima di pasar sehingga gagal mendeteksi adanya indikasi manajemen laba. Tindakan manajemen laba ini tidak dapat diobservasi langsung dari laporan keuangan. Ketidakmampuan pemangku kepentingan untuk mendeteksi tindakan manajemen laba secara dini yang menyebabkan manajemen laba tidak terbukti memediasi pengaruh manajemen laba terhadap kinerja perusahaan. Hasil penelitian ini mendukung penelitian yang dilakukan oleh (Cohen dan Zarowin, 2010).

\section{KESIMPULAN}

Berdasarkan hasil pengujian statistik dan analisis yang telah dijelaskan, maka dapat ditarik kesimpulan sebagai jawaban atas rumusan masalah: (1) CSR memiliki pengaruh positif dan signifikan terhadap Kinerja Perusahaan. Peningkatan CSR dapat dilakukan oleh perusahaan melalui peningkatan kinerja lingkungan, sosial dan ekonomi, yang pada akhirnya dapat meningkatkan kinerja perusahaan; (2) CSR berpengaruh negatif dan signifikan terhadap Manajemen Laba. Dalam hal ini sebuah perusahaan dalam aktivitas CSR harus mendapat dukungan dari masyarakat sekitar berupa laporan keuangan yang lebih terpercaya dan tidak dimanipulasi; (3) Manajemen Laba tidak signifikan terhadap Kinerja Perusahaan. Tujuan dalam perusahaan yakni mendapatkan laba dan penghematan pajak. Seorang manajer lebih memprioritaskan tujuan tersebut; (4) Manajemen Laba tidak dapat memediasi atau tidak memberikan pengaruh CSR terhadap kinerja perusahaan.

Hasil penelitian ini dapat digunakan sebagai bahan pertimbangan bagi perusahaan yang terdaftar di BEI dan yang tergabung dalam indeks saham LQ45 periode 2016-2018 bahwa perusahaan yang sudah komitmen dalam menjalankan kegiatan CSR nantinya lebih mudah menarik para investor. Selain itu dengan adanya kegiatan CSR akan mengurangi praktik dalam manajemen laba sehingga pada laporan keuangan perusahaan akan dibuat dengan sebenarnya dan transparan agar dapat menigkatkan kinerja perusahaan.

\section{DAFTAR PUSTAKA}

Akben-Selcuk, E., 2019. Corporate social responsibility and financial performance: The moderating role of ownership concentration in Turkey. Sustainability, 11(13), p.3643.
Bhernadha, Y.A., Topowijono, T. and Azizah, D.F., 2017. Pengaruh Corporate Social Responsibility Terhadap Kinerja Keuangan Perusahaan (Studi Pada Perusahaan Winner of Sustainability Reporting Award (SRA) 2015 Yang Terdaftar Di BEI Periode 2010-2014. Jurnal Administrasi Bisnis, 44(1), pp.134-143.

Brigham, E.F. and Houston, J.F., 2006. Fundamentals of Financial Management: Dasar-Dasar Manajemen Keuangan. Jakarta: Salemba Empat.

Challen, A.E. and Siregar, S.V., 2017. Audit Quality on Earnings Management and Firm Value. Jurnal Keuangan dan Perbankan, 14(1).

Cho, S. J., Chung, C. Y., \& Young, J. 2019. Study on the Relationship between CSR and Financial Performance. Sustainability, 11(2), 343.

Cohen, D.A. and Zarowin, P., 2010. Accrual-based and real earnings management activities around seasoned equity offerings. Journal of accounting and Economics, 50(1), pp.2-19.

Dyah, H.S.L.P, 2013. Pengaruh Manajemen Laba Akrual Menggunakan Derivatif dan Akrual Terhadap Nilai Perusahaan Dengan Moderasi Corporate Governance dan PSAK 50/55. Tesis Pascasarjana Ilmu Akuntansi. Universitas Indonesia

Ekawiguna, S. M., \& Darmansyah, A. 2017. Effect of corporate social responsibility, corporate governance and earnings management on firm performance at publicly listed Indonesian companies in Indonesia stock exchange. Australian Academy of Accounting and Finance Review, 1(1), 1-28.

Esteban-Sanchez, P., de la Cuesta-Gonzalez, M., Paredes-Gazquez, J.D., 2017. Corporate Social Performance and its relation with Corporate Financial Performance: international evidence in the banking industry. J. Clean. Prod. 162, 11021110.

Fatoni, F., Andini, R. And Raharjo, K., 2016. Pengaruh Kepemilikan Publik, Return On Equity, Current Ratio, Umur Perusahaan Dan Company Size Terhadap Pengungkapan Corporate Social Responbility Pada Perusahaan Real Estate And Property Yang Terdaftar Di Bursa Efek Indonesia Periode 2011-2014. Journal Of Accounting, 2(2).

Fitriyani, Prasetyo, Mirdah \& Putra. 2014. Pengaruh Manajemen Laba Terhadap Kinerja Perusahaan Dengan Kualitas Audit Sebagai Variabel Pemoderasi. Jurnal Dinamika Akuntansi: Vol.6 No 2 Pp 133-141

Fernández-Guadaño, J. and Sarria-Pedroza, J.H., 2018. Impact of corporate social responsibility on value creation from a stakeholder perspective. Sustainability, 10(6), p.2062.

Freeman, R.E. 1983. Strategic Management: A Stakeholder Approach Pitman Publishing Inc., Marshfield, MA.

Gantino. 2016. Pengaruh Tanggung Jawab Sosial Perusahaan Terhadap Kinerja Keuangan Perusahaan 
Manufaktur Yang Terdaftar Di Bursa Efek Indonesia Periode 2008- 2014. Jurnal Dinamika Akuntansi Dan Bisnis Vol. 3 (2), 2016, Hlm 19-32

Ghozali dan Chariri, 2007. Teori Akuntansi. Semarang: Badan Penerbit Undip.

Gray, R., Kouhy, R., \& Lavers, S. 1995. Constructing a research database of social and environmental reporting by UK companies. Accounting, Auditing \& Accountability Journal. 28(3), 327-356

Hadi, N. 2011. Corporate Social Responsibility. Yogyakarta: Graha Ilmu

Kamatra, N., \& Kartikaningdyah, E. 2015. Effect corporate social responsibility on financial performance. International Journal of Economics and Financial Issues, 5(1S), 157-164.

Kim, Y., Park., M.S., Wier, B. 2012. Is Earnings Quality associated with Corporate Social Responsibility? The Account Rev. 87(3), 761-796.

Lenssen, G., Blagov, Y., Bevan, D., Chen, H. and Wang, X., 2011. Corporate social responsibility and corporate financial performance in China: an empirical research from Chinese firms. Corporate Governance: The international journal of business in society.

Lestari dan Anjelina 2014. Pengaruh Manajemen Laba terhadap Kinerja Perusahaan. (Online): https://repository.polibatam.ac.id/ uploads/211107-20170929090947.pdf

Mahrani, M., \& Soewarno, N. 2018. The effect of good corporate governance mechanism and corporate social responsibility on financial performance with earnings management as mediating variable. Asian Journal of Accounting Research. Vol. 3 No. 1, pp. 41-60

Mulyadi. 2001. Sistem Akuntansi Edisi Tiga. Jakarta: Salemba Empat.

Mwangi, C., \& Jerotich, O. 2013. The Relationship between Corporate Social Responsibility Practices and Financial Performance of Firms in the Manufacturing, Construction and Allied Sector of the Nairobi Securities Exchange. International Journal of Business, Humanities and Technology, 3(2), $1-10$

Nastiti, A. R. 2010. Pengaruh corporate social responsibility terhadap manajemen laba (Studi pada perusahaan manufaktur yang listingdi bursa efek Indonesia periode 2005-2008), (Online): http:// library.um.ac.id/free-contents/download/pub/pub. php/41684.pdf

Parengkuan, W. E. 2017. Pengaruh Corporate Social Responsibility (CSR) terhadap Kinerja Keuangan Perusahaan Manufaktur yang Terdaftar di Bursa Efek Indonesia Melalui Pojok Bursa FEB-UNSRAT. Jurnal EMBA: Jurnal Riset Ekonomi, Manajemen, Bisnis dan Akuntansi, 5(2).

Putra, I. and Palguna, A.W., 2013. Pengaruh Tingkat Pengungkapan Item Corporate Social Responsibility
Terhadap Manajemen Laba (Studi Pada Perusahaan Yang Terdaftar Di Indeks Sri-Kehati Selamatahun 2009-2011). Skripsi, Pogram Sarjana Universitas Atma Jaya, Yogyakarta.

Pramana, I G. A. \& Yadnyana, I K. 2016. Tanggung Jawab Sosial Perusahaan Pengaruh Pada Kinerja Perusahaan Manufaktur. E-Jurnal Akuntansi Universitas Udayana Vol.16.3. September: 1965-1988

Prasetyo, Wika S, S. \& Harjanto, S. 2017. Pengaruh Manajemen Laba Terhadap Kinerja Perusahaan Dengan Tata Kelola Perusahaan Sebagai Variabel Yang Baik Moderasi (Studi Kasus Pada Perusahaan Manufaktur Yang Terdaftar Di Bei Tahun 2011 2014. Thesis: STIE Dharmaputra Semarang

Putri, A. R. S.. 2012. Pengaruh Pengungkapan Corporate Social Responsibility Terhadap Manajemen Laba (Studi Kasus pada Perusahaan Manufaktur yang Terdaftar di Bursa Efek Indonesia Tahun 20082011). Skripsi: Universitas Sebelas Maret, Surakarta Ricardo, D.M. and Faisal, F., 2015. Pengaruh Pengungkapan Corporate Social Responsibility Terhadap Praktik Manajemen Laba. Diponegoro Journal of Accounting, 4(2), pp.33-42.

Ross, W. Dan Jordan. 2009. Corporate Finance Fudamentals : Pengantar Keuangan Perusahaan. Terjemahan Ali Akbar Yulianto, Rafika Yuniasih Dan Christine. Jakarta: Salemba Empat.

Saleh, M., Zulkifli, N. and Muhamad, R. 2011. Looking for evidence of the relationship betweencorporate social responsibility and corporate financial performance in an emerging market, Asia-Pacific Journal of Business Administration, Vol. 3 No. 2, pp. 165-190.

Santoso, R. V. 2017. Pengaruh pengungkapan Corporate Social Responsibility (CSR) terhadap kinerja keuangan: Studi empiris pada perusahaan manufaktur industri konsumsi yang terdaftar di BEI Tahun 2011-2015 (Doctoral dissertation, Universitas Islam Negeri Maulana Malik Ibrahim).

Scholtens, B. \& Kang, F.C. 2012. Corporate Social Resposibility and Earnings Management : Evidence from Asian Economics dalam Wiley Online Library

Scott, R. W. 2006. Financial Accounting Theory $4^{\text {th }}$ edition. New Jersey: Prentice-Hall.

Scott, William R, 2009. Financial Accounting Theory. Fifth Edition. Canada Prentice Hall.

Simaremare, H.R. and Gaol, R.L., 2019. Pengaruh Corporate Sosial Responsibility (CSR) terhadap kinerja keuangan pada perusahaan makanan dan minuman yang terdaftar di Bursa Efek Indonesia. Jurnal RisetAkutansi dan Keuangan, 4(2), pp.157-174.

Yip, W. H. \& Nguyen, H. 2012. Exchange rate exposure and the use of foreign currency derivatives in the Australian resources sector. School of Accounting, Economics and Finance,Faculty of Business and Law, Deakin University, 221 Burwood Highway, Burwood, VIC 3125, Australia 


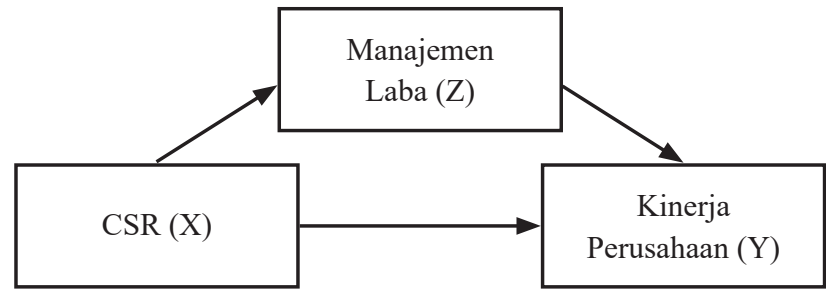

Gambar 1.

Tabel 1. Prosedur Pemilihan Sampel

\begin{tabular}{lc}
\hline \multicolumn{1}{c}{ Kriteria sampel } & $\begin{array}{c}\text { Jumlah } \\
\text { perusahaan }\end{array}$ \\
\hline Perusahaan yang terdaftar dalam Perusahaan LQ 45 & 45 \\
Perusahaan yang tidak terdaftar dalam Perusahaan & $(11)$ \\
LQ45 periode 2016 - 2018 & \\
Perusahaan yang tidak memiliki data lengkap terkait & $(3)$ \\
variabel yang digunakan & \\
Jumlah perusahaan sampel & 31 \\
Periode penelitian & 3 Tahun \\
Jumlah observasi & 93 \\
\hline
\end{tabular}

Tabel 2. Statistif Deskriptif Variabel

\begin{tabular}{lcccc}
\hline & Min & Max & Mean & Dev. Std \\
\hline CSR & 0,36 & 1,95 & 0,7316 & 0,42687 \\
Kinerja Perusahaan & 0,02 & 1,22 & 0,2742 & 0,30233 \\
Manajemen Laba & 0,03 & 4,88 & 0,6507 & 0,92270 \\
\hline
\end{tabular}

Tabel 3. Pengaruh Langsung Antar Variabel

\begin{tabular}{lccc}
\hline \multicolumn{1}{c}{ Pengaruh } & $\begin{array}{c}\text { Koefisien } \\
\text { Jalur }\end{array}$ & p value & Keterangan \\
\hline $\mathrm{CSR} \rightarrow$ Kinerja & 0,680 & 0,000 & Signifikan \\
$\mathrm{CSR} \rightarrow$ Manajemen Laba & $-0,301$ & 0,000 & Signifikan \\
$\begin{array}{l}\text { Manajemen laba } \rightarrow \text { Kinerja } \\
\text { perusahaan }\end{array}$ & $-0,207$ & 0,114 & Tidak \\
& & & Signifikan \\
\hline
\end{tabular}

Tabel 4. Pengaruh CSR Terhadap Manajemen Laba

\begin{tabular}{lcccc}
\hline & \multicolumn{3}{c}{ Pengaruh } & \multirow{2}{*}{ Keterangan } \\
\cline { 2 - 4 } & langsung & tidak langsung & total & \\
\hline CSR & 0,680 & -0.207 & 0,473 & Tidak Signifikan \\
\hline
\end{tabular}

